\title{
International Committee on Systematic Bacteriology Subcommittee on the Taxonomy of Campylobacter and Related Bacteria
}

\author{
Minutes of the Meeting, 22 September 1993, Brussels Belgium
}

\section{Session 1. Closed meeting.}

Minute 1. Call to order. The Acting Chairman, R. J. Owen, called the closed meeting to order at 15:10 on 22 September 1993.

Minute 2. Record of attendance. The members present were J. Fox, A. Lee, H. Lior, F. Megraud, and R. J. Owen (Acting Chairman and Acting Secretary).

Minute 3. Apologies for absence. Apologies for absence had been received from J. Ursing, J. P. Butzler, and M. A. Karmali.

Minute 4. Minutes of the previous meeting. The minutes of the meeting held in Osaka, Japan, on 13 September 1990, which had been published, were approved.

Minute 5. Agenda. The agenda was approved as circulated.

Minute 6. Matters concerning membership. Two new members (R. Megraud and A. Lee) were welcomed to the subcommittee.

Minute 7. Amendment to Article 9.2 of the ICSB statutes. It was agreed that J. Ursing should write to the International Committee on Systematic Bacteriology (ICSB) Executive Secretary to suggest amendments to Article 9.2 of the ICSB statutes which would allow subcommittees to vote on nominations without having to first submit such nominations to the ICSB Secretary for Subcommittees on Taxonomy.

Minute 8. Recent developments in the genus Campylobacter and related bacteria. Progress on a document entitled "Propos- al of minimal standards for describing new species of Campylobacteraceae" was discussed. The taxonomic rearrangement of the campylobacters and the many new species proposed since 1990 made several changes necessary and delayed the final version. The document has now been sent to the ICSB Editorial Secretary. The following new species have been described: Campylobacter helveticus, Campylobacter showii, and Helicobacter canis.

Minute 9. Next meeting. The next meeting of the subcommittee will be held during the International Union of Microbiological Sciences meeting in Prague, Czech Republic, in July 1994.

Minute 10. Current membership. The members of the subcommittee are as follows: J. H. Bryner (United States), J. P. Butzler (Belgium), F. G. Fox (United States), M. A. Karmali (Secretary) (Canada), A. Lee (Australia), H. Lior (Canada), F. Megraud (France), R. J. Owen (United Kingdom), C. M. Patton (United States), J. L. Penner (Canada), R. Sakazaki (Japan), T. J. Trust (Canada), and J. B. Ursing (Chairman) (Sweden).

Minute 11. Adjoumment. The meeting was adjourned at 15:45 on 22 September 1993.

R. J. Owen, Acting Chairman and Acting Secretary 